Article

\title{
Two Different Copy Number Variations of the CLCN2 Gene in Chinese Cattle and Their Association with Growth Traits
}

\author{
Jia Tang ${ }^{1}$, Xuemei Shen ${ }^{1}$, Yu Yang ${ }^{1}$, Haiyan Yang ${ }^{1}$, Ao Qi ${ }^{1}$, Shuling Yang ${ }^{1}$, Kaixing $Q u^{2}$, Xianyong Lan ${ }^{1}$, \\ Bizhi Huang ${ }^{3, *}$ and Hong Chen ${ }^{1,4, *}$ (1)
}

1 Key Laboratory of Animal Genetics, Breeding and Reproduction of Shaanxi Province, College of Animal Science and Technology, Northwest A\&F University, Xianyang 712100, China; candy2038@nwafu.edu.cn (J.T.); shenxuemei@nwafu.edu.cn (X.S.); yangyu921048495@nwafu.edu.cn (Y.Y.); yanghaiyan0316@nwafu.edu.cn (H.Y.); 18734453163@nwafu.edu.cn (A.Q.); yangshuling@nwafu.edu.cn (S.Y.); lan342@126.com (X.L.)

2 Academy of Science and Technology, Chuxiong Normal University, Chuxiong 675000, China; kaixqu@163.com

3 Yunnan Academy of Grassland and Animal Science, Kunming 650212, China

4 College of Animal Science, Xinjiang Agricultural University, Urumqi 830052, China

* Correspondence: chenhong1212@263.net (H.C.); hbz@ynbp.cn (B.H.)

check for

updates

Citation: Tang, J.; Shen, X.; Yang, Y.; Yang, H.; Qi, A.; Yang, S.; Qu, K.; Lan, X.; Huang, B.; Chen, H. Two Different Copy Number Variations of the CLCN2 Gene in Chinese Cattle and Their Association with Growth Traits. Animals 2022, 12, 41. https:// doi.org/10.3390/ani12010041

Received: 25 November 2021 Accepted: 21 December 2021 Published: 26 December 2021

Publisher's Note: MDPI stays neutral with regard to jurisdictional claims in published maps and institutional affiliations.

Copyright: (C) 2021 by the authors. Licensee MDPI, Basel, Switzerland. This article is an open access article distributed under the terms and conditions of the Creative Commons Attribution (CC BY) license (https:// creativecommons.org/licenses/by/ $4.0 /)$.
Simple Summary: Compared with traditional breeding methods, molecular marker breeding can greatly speed up the process of livestock breeding to improve the production performance of economic traits. As one form of genetic variation, copy number variations could be used for molecular marker breeding. This study explored CNVs in bovine CLCN2 genes on account of this gene possibly being involved in cell volume regulation, transepithelial transport and cell proliferation. We investigated their association with growth traits in four Chinese cattle breeds. Our results provide evidence that there are two different copy number variations in CLCN2, which are associated with growth traits in two different Chinese cattle populations and could be used as candidate markers for cattle molecular breeding.

Abstract: Copy number variation $(\mathrm{CNV})$ can affect gene function and even individual phenotypic traits by changing the transcription and translation level of related genes, and it also plays an important role in species evolution. Chloride voltage-gated channel 2 (CLCN2) encodes a voltagegated chloride channel (CLC-2), which has a wide organ distribution and is ubiquitously expressed. Based on previous studies, we hypothesize that CLCN2 could be a candidate gene involved in cell volume regulation, transepithelial transport and cell proliferation. This study aimed to explore CNVs in the CLCN2 gene and investigate its association with growth traits in four Chinese cattle breeds (Yunling cattle, Xianan cattle, Qinchuan cattle and Pinan cattle). We identified there are two copy number variation regions (CNV1: $3600 \mathrm{bp}$, including exon 2-11; CNV2: $4800 \mathrm{bp}$, including exon 21-22) of the CLCN2 gene. The statistical analysis showed that the CNV1 mutation in the YL cattle population was significantly associated with cannon circumference $(p<0.01)$. The CNV2 mutation in the $\mathrm{XN}$ cattle population had a significant effect on body slanting length, chest girth and body weight $(p<0.05)$. In the YL cattle, the association analysis of CLCN2 gene CNV1 and CNV2 combination with cannon circumference was significant $(p<0.01)$. Our results provide evidence that CNV1 and CNV2 in CLCN2 are associated with growth traits in two different cattle populations and could be used as candidate markers for cattle molecular breeding.

Keywords: $\mathrm{CNV}$; chloride voltage-gated channel 2; bovine; body size data

\section{Introduction}

Beef is an important food source of protein for human beings. In recent years, the quantity and quality of beef consumption have been greatly improved in China [1]. Continuous breeding can improve the production performance of economic traits, while the traditional breeding methods usually need several generations and a long process. Molecular marker 
breeding can greatly accelerate the breeding process of livestock [2]. Various genes regulate meat traits, and we can study their genetic variations for marker assisted selection [3]. As a new form of genetic variation, copy number variation (CNV) is defined as a large-scale structural variation between $50 \mathrm{bp}$ and $5 \mathrm{Mb}$ in the genome, including the insertion, deletion, duplication and complex mutations at multiple chromosomal sites [4]. Compared with single nucleotide polymorphism (SNP), copy number variation has fewer variation sites and longer sequences, making it easier to detect and study. $\mathrm{CNV}$ can affect gene function and even individual phenotypic traits by changing the transcription and translation levels of related genes, and it also plays an important role in species evolution. The genomic CNV data of several breeds of cattle have been published [5,6], showing that CNV is closely related to the health status and economic traits of cattle. Therefore, it has broad prospects and is of great significance to speed up the process of breeding improvement.

Chloride voltage-gated channel 2 (CLCN2) encodes a voltage-gated chloride channel (CLC-2), which has a wide organ distribution and is ubiquitously expressed. The encoded protein is a transmembrane protein that maintains chloride ion homeostasis in various cells and is critical for electrogenesis, homeostatic control of cell volume, and maintenance of ion gradients [7]. Volume-activated chloride channels (VACCs) may participate in cell proliferation and apoptosis [8] through cell swelling as well as shrinkage [9] and is involved in migratory capacity and cell proliferation [10]. Many studies have proved that some $\mathrm{Cl}^{-}$channel blockers affect the proliferation of a variety of cell types, such as endothelial cells [11], vascular smooth muscle cells [12], glioma cells [13], intestinal enterocytes [14] and human leukemic cells [15]. Meanwhile, the current study indicates that voltage-gated CLC-2 may serve as an important positive regulator in oligodendrocyte precursor cell differentiation by regulating the expression of myelin gene transcription factors [16]. Studies have provided data to demonstrate that CLCN2 plays a role in the IGF-1-induced regulation of vascular smooth muscle cell proliferation in cardiovascular diseases [17]. It might also exert functions via the PI3K/AKT and the Wnt/ $\beta$-catenin signaling pathways $[18,19]$. Previous studies have pointed out that the function and regulation of $\mathrm{ClC}-2$ are highly conservative among different species [20]. From the above, we hypothesize that the CLCN2 gene could be a candidate gene for involvement in cell volume regulation, transepithelial transport and cell proliferation [21].

There are several prominent beef cattle breeds in China, and each breed has a specific genetic background. Yunling cattle (YL) is the first cattle breed bred by ternary cross breeding including Brahman, Murray Grey and Yunnan native cattle. Xianan cattle $(\mathrm{XN})$ is the cultivate breed hybrid of French Charolais cattle and Nanyang cattle, which was the first beef cattle breed in China. Qinchuan cattle $(Q C)$ is one of China's five major varieties and has become an important source of increased income for farmers in many Chinese provinces. Pinan cattle (PN) is a hybrid between Piedmont cattle and Nanyang cattle in China with excellent performance that has much room for improvement. In brief, these cattle breeds play an irreplaceable role in China's animal husbandry industry and have great potential.

In this study, we analyzed the associations between CNVs (CNV1: $3600 \mathrm{bp}$, including exon 2-11; CNV2: $4800 \mathrm{bp}$, including 21-22 exon) of the CLCN2 gene and the growth traits of Yunling cattle, Xianan cattle, Qinchuan cattle and Pinan cattle. The results show that CNVs of CLCN2 gene could be used as candidate markers for cattle molecular breeding.

\section{Materials and Methods}

\subsection{Animals and Growth Traits Measurements}

The study used the blood samples of adult female cattle, which were freely-fed with corn silage. We selected a total of 573 cattle from four kinds of cattle to study the copy number variations of the $C L C N 2$ gene: Yunling cattle ( $\mathrm{YL}, n=176$, Kunming City, Yunnan Province, China), Xianan cattle (XN, $n=97$, Zhumadian City, Henan Province, China), Qinchuan cattle (QC, $n=34$, Baoji City, Shaanxi Province, China), Pinan cattle (PN, $n=266$, Nanyang City, Henan Province, China). 
We measured the corresponding growth traits of these 573 cattle. For YL, we measured body height $(\mathrm{BH})$, hip height $(\mathrm{HH})$, body slanting length (BSL), chest girth (CG), abdominal girth (AG), cannon circumference (CC), chest width (CW), chest depth (CD), hip girth (HG), hucklebone width (HBW), hip width (HW), rump length (RL) and body weight (BW). In the $\mathrm{XN}$ population, body height $(\mathrm{BH})$, hip height $(\mathrm{HH})$, body slanting length $(\mathrm{BSL})$, chest girth (CG), abdominal girth (AG), cannon circumference (CC) and body weight (BW) were measured. For QC, we measured body height $(\mathrm{BH})$, hip height $(\mathrm{HH})$, body length (BL), chest girth (CG), chest width (CW), chest depth (CD), rump length (RL), hip width (HW), hucklebone width (HBW) and body weight (BW). In the PN population, body height $(\mathrm{BH})$, body slanting length (BSL), hip height (HH), chest girth (CG), hucklebone width (HBW) and rump length (RL) were measured.

\subsection{Preparation of Sample and Genomic DNA}

This study collected all the blood samples of the cattle and used a standard phenolchloroform protocol to extract genomic DNA [22]. Nanodrop 2000 was used to determine the quantity of genomic DNA. Then, the DNA samples were diluted to $25 \mathrm{ng} / \mu \mathrm{L}$ and stored at $-40{ }^{\circ} \mathrm{C}$.

\subsection{Candidate Gene Identification and Primer Design}

According to existing comparative genomic hybridization (CGH) analysis results, we identified two copy number variation regions in the CLCN2 gene (AC_000158.1) located at Chr1:83,444,939 to 83,448,538 bp (3600 bp) and Chr1:83,451,739 to 83,456,138 bp (4400 bp) in Chinese cattle. Information about the CLCN2 gene primers is shown in Figure 1 and Table 1. The orange boxes in Figure 1 represent coding regions. All primers were designed by NCBI primer blast. We found that the CLCN2 gene was located in QTLs associated with intramuscular fat, body weight (birth) and fat thickness at the 12th rib (Figure 2).

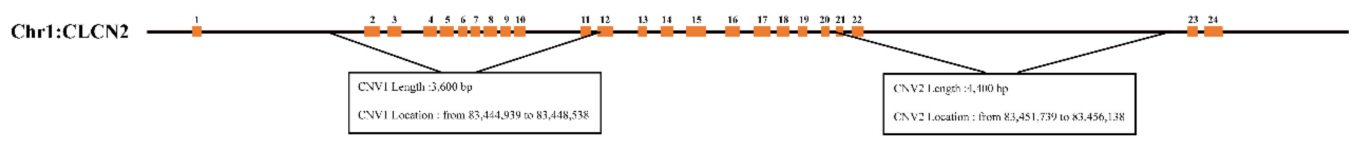

Figure 1. Information about the two CNV regions of CLCN2 gene in cattle breeds.

Table 1. Primers designed for the genes used in this study.

\begin{tabular}{ccc}
\hline Genes & Sequences $\left(\mathbf{5}^{\prime} \mathbf{- 3}^{\prime} \mathbf{)}\right.$ & Amplification Length \\
\hline \multirow{2}{*}{ CLCN2-CNV1 } & $\begin{array}{c}\text { Forward primer: TTCAGCGCCTTCATCTTCCG } \\
\text { Reverse primer: GCCCCACCTCATCTGAAACAT }\end{array}$ & $104 \mathrm{bp}$ \\
CLCN2-CNV2 & $\begin{array}{c}\text { Forward primer: TGGGGAGTCTGGGGTCTAAC } \\
\text { Reverse primer: TCCTCACCAGGATAGGGCTG } \\
\text { BTF3 }\end{array}$ & $\begin{array}{c}\text { Forward primer: AACCAGGAGAAACTCGCCAA } \\
\text { Reverse primer: TTCGGTGAAATGCCCTCTCG }\end{array}$ \\
\hline
\end{tabular}

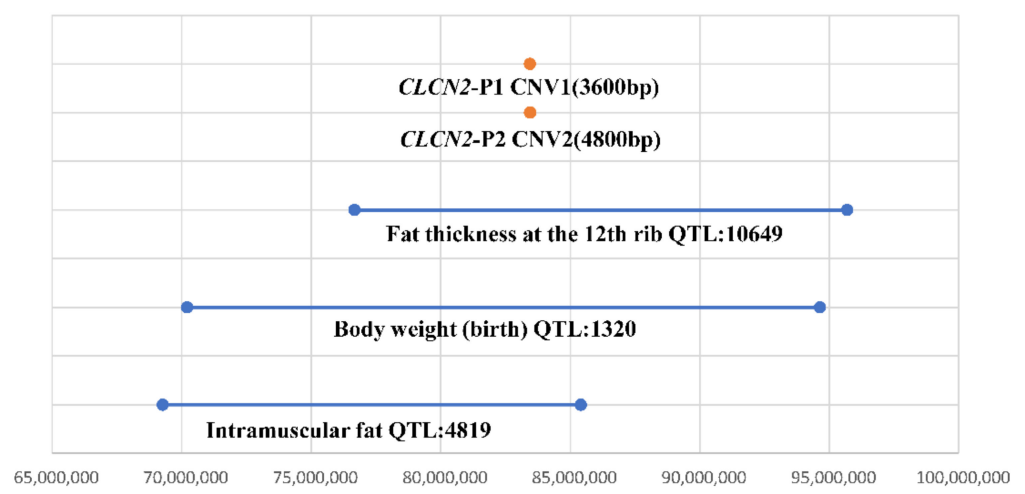

Figure 2. The two CNV regions of the CLCN2 gene overlap with the QTLs of the cattle. 


\subsection{Detection of the CLCN2 Gene Copy Number}

In this study, quantitative polymerase chain reaction (qPCR) was used to determine the copy number of potential CNVs. The bovine basic transcription factor 3 (BTF3) gene was the housekeeping gene. The $10 \mu \mathrm{L}$ reaction mixtures contained $25 \mathrm{ng}$ of genomic DNA, $0.5 \mu \mathrm{L}$ of primers, $5 \mu \mathrm{L}$ of ChamQ SYBR qPCR Master Mix (Vazyme, Nanjing, China) and $3 \mu \mathrm{L}$ of $\mathrm{ddH}_{2} \mathrm{O}$. The thermal cycling conditions were $95{ }^{\circ} \mathrm{C}$ for $30 \mathrm{~s}$ followed by 40 cycles of $95^{\circ} \mathrm{C}$ for $10 \mathrm{~s}$ and $60^{\circ} \mathrm{C}$ for $30 \mathrm{~s}$.

\subsection{Statistical Analysis}

In this study, the copy number $(\mathrm{CN})$ of the CLCN2 gene was analyzed using $2 \times 2^{-\Delta \Delta C t}[23,24]$. The copy number was divided into three types for each region: loss $(\mathrm{CN}<2)$, median $(\mathrm{CN}=2)$ and gain $(\mathrm{CN}>2)$. Thus, there were nine types of the copy number of the CLCN2 CNV1 and CNV2 combination: loss and loss $(\mathrm{CN} 1<2, \mathrm{CN} 2<2)$, loss and normal $(\mathrm{CN} 1<2, \mathrm{CN} 2=2)$, loss and gain $(\mathrm{CN} 1<2, \mathrm{CN} 2>2)$, normal and loss $(\mathrm{CN} 1=2, \mathrm{CN} 2<2)$, normal and normal $(\mathrm{CN} 1=2, \mathrm{CN} 2=2)$, normal and gain $(\mathrm{CN} 1=2$, $\mathrm{CN} 2>2)$, gain and loss $(\mathrm{CN} 1>2, \mathrm{CN} 2<2)$, gain and normal $(\mathrm{CN} 1>2, \mathrm{CN} 2=2)$, gain and gain $(\mathrm{CN} 1>2, \mathrm{CN} 2>2)$. We analyzed the associations of $C L C N 2 \mathrm{CNVs}$ with growth traits in $\mathrm{YL}, \mathrm{XN}, \mathrm{QC}$ and $\mathrm{PN}$ cattle using the one-way analysis of variance (ANOVA) technique in IBM SPSS Statistics 23 software. On the basis of different factors affecting growth traits in cattle, considering age and genetic effects, we used the general linear model method, and predigested for the current situation. The finished model employed Equation (1), in which $Y_{i j k}$ is the record of individual phenotypes, $u$ is population mean, $A_{i}$ is the effect due to age, $C N V_{j}$ is the fixed effect of $C N V$ type of the $C L C N 2$ gene and $e_{\mathrm{ijk}}$ is random error.

$$
Y_{i j k}=\mu+A_{i}+C N V_{j}+e_{i j k}
$$

\section{Results}

\subsection{Distribution of CNVs of CLCN2 Gene in the Experimental Sample Group}

To study the distribution of CLCN2 CNVs in different Chinese cattle breeds, we detected the copy number of CLCN2 in four cattle breeds, including YL, XN, QC, and PN. The three basic types (loss, normal and gain) and the nine combined types (LL, LN, LG, $\mathrm{NL}, \mathrm{NN}, \mathrm{NG}, \mathrm{GL}, \mathrm{GN}$ and GG) of CNV were classified, as mentioned above. As shown in Figure $3 a, b$, the results revealed the copy number of the CLCN2 genes CNV1 and CNV2 was basically consistent in distribution. The frequency of the copy number polymorphisms of the CLCN2 gene (Figure 3c,d) illustrated that the loss type was maximal in YL and the gain type was maximal in QC and PN; these results were similar for both CNV1 and CNV2. Therefore, as the frequency of the copy numbers of the CLCN2 gene CNV1 and CNV2 combination shows, the loss and loss type was the main type in $\mathrm{YL}$ and the gain and gain type was the main type in QC and PN. For XN, the main type was the normal type in CNV1, the loss type in CNV2, and the normal and loss type in the CNV1 and CNV2 combination (Figure 3e). 

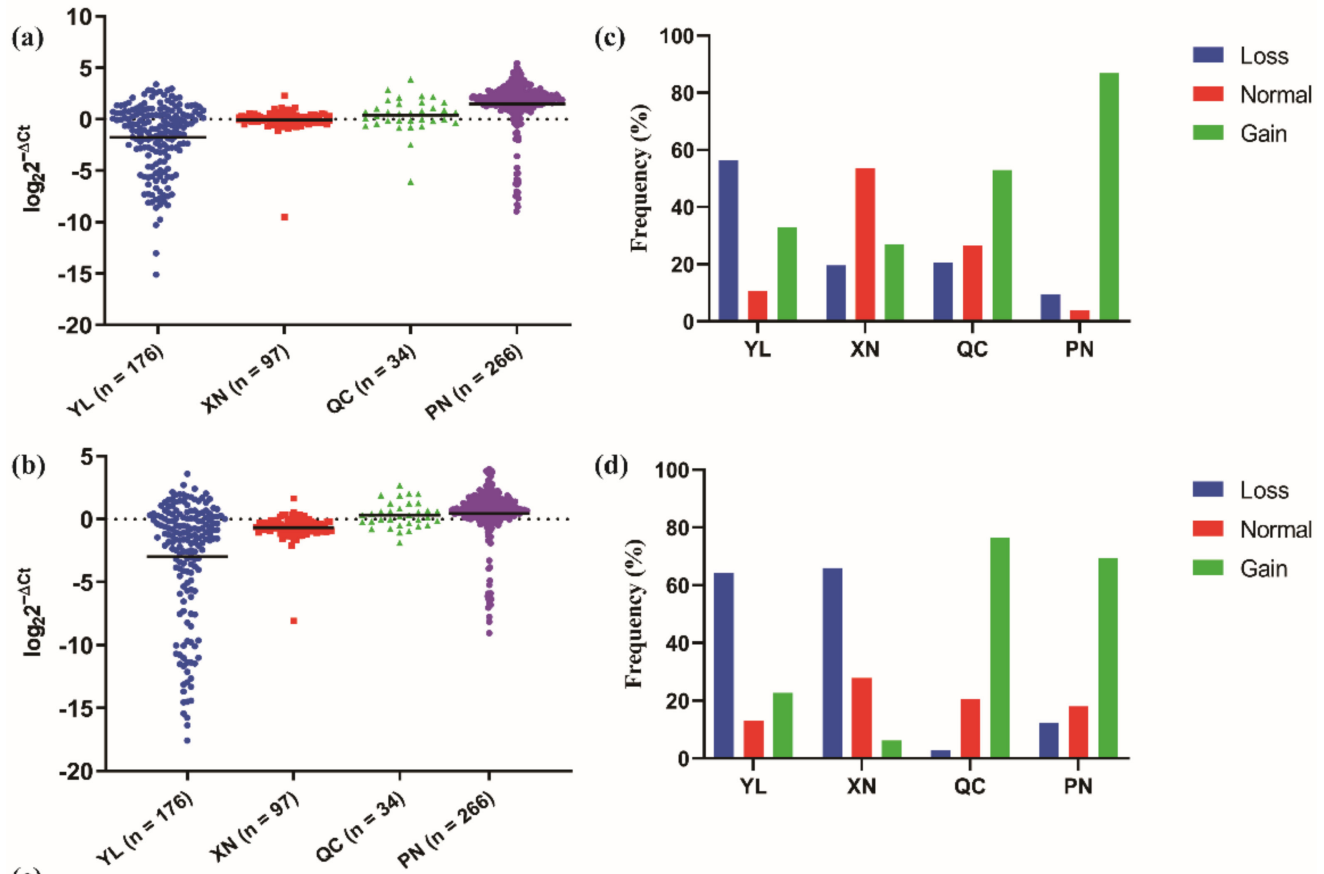

(e)

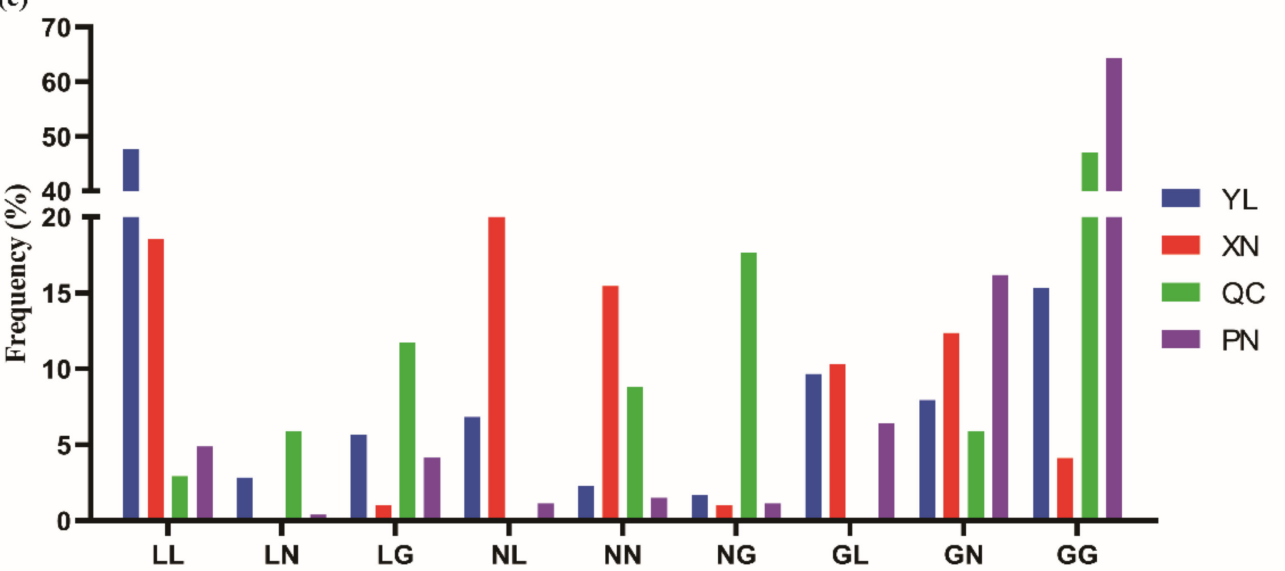

Figure 3. The distribution of the $C L C N 2$ gene $C N V 1$ and CNV2 and their combination in the different Chinese cattle breeds. (a) The distribution of CLCN2 gene CNV1 copy numbers in four Chinese cattle breeds. (b) The distribution of CLCN2 gene CNV2 copy numbers in four Chinese cattle breeds. (c) The frequency of the copy numbers of the CLCN2 gene CNV1 in four Chinese cattle breeds.

(d) The frequency of the copy numbers of the CLCN2 gene CNV2 in four Chinese cattle breeds.

(e) The frequency of the copy numbers of the CLCN2 gene CNV1 and CNV2 combination in four Chinese cattle breeds. LL means loss and loss; LN means loss and normal; LG means loss and gain; NL means normal and loss; NN means normal and normal; NG means normal and gain; GL means gain and loss; GN means gain and normal; GG means gain and gain. YL-Yunling cattle; XN-Xianan cattle; QC-Qinchuan cattle; PN_Pinan cattle.

\subsection{Association Analysis}

In this study, we analyzed the association of the CLCN2 gene copy number types with the growth traits of four Chinese cattle breeds using a general linear model. The association showed that that the CNV1 mutation in the YL cattle population significantly affected cannon circumference $(p=0.002)$, as well as that cattle with the loss type of CNV1 had higher cannon circumference than those with the normal or gain type (Table 2). The CNV2 mutation in the $\mathrm{XN}$ cattle population had a significant effect on body slanting length $(p=0.031)$, chest girth $(p=0.025)$ and body weight $(p=0.034)$, which were higher for individuals with the normal type of CNV2 than with the loss or gain type (Table 3). In YL cattle, the association analysis of the CLCN2 gene CNV1 and CNV2 combination with 
growth traits showed cattle with the loss and normal type had significantly better traits than those with other types in cannon circumference $(p=0.006)$ (Table 4$)$.

Table 2. Association analysis of CLCN2 gene CNV1 with growth traits in YL cattle.

\begin{tabular}{|c|c|c|c|c|c|}
\hline \multirow{2}{*}{ Breed } & \multirow{2}{*}{ Growth Traits } & \multicolumn{3}{|c|}{ CNV Types (Mean \pm SE) } & \multirow{2}{*}{$p$-Value } \\
\hline & & Loss $(n=99)$ & Normal $(n=19)$ & Gain $(n=58)$ & \\
\hline Yunling cattle & cannon circumference $(\mathrm{cm})$ & $18.88 \pm 0.140^{\mathrm{A}}$ & $18.47 \pm 0.269^{\mathrm{AB}}$ & $17.74 \pm 0.360^{\mathrm{B}}$ & $0.002 * *$ \\
\hline
\end{tabular}

$\mathrm{A}$ and $\mathrm{B}$ denote values that differ significantly at ${ }^{* *}, p<0.01$.

Table 3. Association analysis of CLCN2 gene CNV2 with growth traits in XN cattle.

\begin{tabular}{|c|c|c|c|c|c|}
\hline \multirow{2}{*}{ Breed } & \multirow{2}{*}{ Growth Traits } & \multicolumn{3}{|c|}{ CNV types (Mean \pm SE) } & \multirow{2}{*}{$p$-Value } \\
\hline & & Loss $(n=64)$ & Normal $(n=27)$ & Gain $(n=6)$ & \\
\hline \multirow{3}{*}{ Xianan cattle } & body slanting length $(\mathrm{cm})$ & $158.09 \pm 0.707^{\mathrm{a}}$ & $161.59 \pm 1.591^{b}$ & $155.50 \pm 2.717^{\mathrm{ac}}$ & 0.031 * \\
\hline & chest girth $(\mathrm{cm})$ & $191.61 \pm 1.019^{a}$ & $196.67 \pm 1.768^{b}$ & $189.83 \pm 3.156^{\mathrm{ab}}$ & $0.025 *$ \\
\hline & body weight (kg) & $543.19 \pm 6.694^{\mathrm{a}}$ & $574.48 \pm 13.627^{b}$ & $523.00 \pm 11.897 \mathrm{ab}$ & 0.034 * \\
\hline
\end{tabular}

$\mathrm{a}, \mathrm{b}$ and $\mathrm{c}$ denote values that differ significantly at ${ }^{*}, p<0.05$.

Table 4. Association analysis of CLCN2 gene CNV1 and CNV2 combination with growth traits in YL cattle.

\begin{tabular}{|c|c|c|c|c|c|c|c|c|c|c|c|}
\hline \multirow{2}{*}{ Breed } & \multirow{2}{*}{$\begin{array}{l}\text { Growth } \\
\text { Traits }\end{array}$} & \multicolumn{9}{|c|}{ CNV types (Mean \pm SE) } & \multirow{2}{*}{$p$-Value } \\
\hline & & LL (84) & LN (5) & LG (10) & NL (12) & NN (4) & NG (3) & GL (17) & GN (14) & GG (27) & \\
\hline $\begin{array}{l}\text { Yunling } \\
\text { cattle }\end{array}$ & $\begin{array}{l}\text { cannon } \\
\text { circumference } \\
(\mathrm{cm})\end{array}$ & $\begin{array}{c}18.84 \pm \\
0.147^{\mathrm{Aab}}\end{array}$ & $\begin{array}{c}19.80 \pm \\
0.917^{\mathrm{Aab}}\end{array}$ & $\begin{array}{c}18.80 \pm \\
0.442^{\mathrm{Aab}}\end{array}$ & $\begin{array}{c}18.33 \pm \\
0.284^{\mathrm{ABa}}\end{array}$ & $\begin{array}{c}18.75 \pm \\
0.946^{\mathrm{ABa}}\end{array}$ & $\begin{array}{c}18.67 \pm \\
0.667^{\mathrm{ABab}}\end{array}$ & $\begin{array}{c}18.06 \pm \\
0.369 \mathrm{ABa}\end{array}$ & $\begin{array}{l}16.50 \pm \\
1.300^{\mathrm{Bb}}\end{array}$ & $\begin{array}{c}18.19 \pm \\
0.283^{\mathrm{ABa}}\end{array}$ & $0.006^{* *}$ \\
\hline
\end{tabular}

a and $\mathrm{b}$ denote values that differ significantly, $p<0.05 ; \mathrm{A}$ and $\mathrm{B}$ denote values that differ significantly at **, $p<0.01$. LL means loss and loss; LN means loss and normal; LG means loss and gain; NL means normal and loss; NN means normal and normal; NG means normal and gain; GL means gain and loss; GN means gain and normal; GG means gain and gain.

\section{Discussion}

Genetic variation takes many forms, ranging from large chromosome anomalies to single nucleotide changes. Various studies have discovered an abundance of copy number variations of DNA segments varying from kilobases $(\mathrm{kb})$ to megabases $(\mathrm{Mb})$ in size [25,26]. With the latest development of high throughput sequencing technology, a larger number of CNVs have been identified in many animal husbandry species, such as chicken [27], pig [28,29], cattle [30,31] and sheep [32]. By molecular mechanisms, such as gene disruption, gene fusion, positive effect and dosage effect, CNVs could be associated with complex disease or quantitative traits [33]. Many studies have worked on the CNV-associated, economically important traits in the genomes of livestock [34,35].

The CLCN2 gene is expressed in many different tissues and its physiological functions are quite diverse, including transepithelial fluid transport, cell volume regulation and neuronal chloride homeostasis regulation $[21,36,37]$. Chloride channels modify cytoplasmic $\mathrm{Cl}^{-}$activity and mediate osmolyte flux, thus affecting cell volume. Most chloride channels allow the exit of $\mathrm{HCO}_{3}{ }^{-}$, leading to cytosolic acidification, thereby inhibiting cell proliferation and promoting cell apoptosis [38]. In addition, it has been proved the $\mathrm{Cl}^{-}$channel blockers may perturb the intracellular ionic environment, resulting in G0/G1 arrest via the p21 pathway [15]. The CLCN2 gene is closely related to cell proliferation and apoptosis, which provides a reliable theoretical basis for the necessity of this study. However, a detailed explanation of the function of the CLCN2 gene in Chinese cattle is lacking, making it a relatively unknown area that still needs extensive study.

In this research, we found that the CNV regions of the CLCN2 gene overlapped with the QTL regions correlated with intramuscular fat, body weight (birth) and fat thickness 
at the 12th rib. Therefore, we inferred that the copy number variation of the CLCN2 gene may be related to the growth traits of cattle. We chose four Chinese cattle breeds (Yunling cattle, Xianan cattle, Qinchuan cattle and Pinan cattle) to explore CNVs in CLCN2 gene and investigate their association with growth traits. The results showed the CNVs of the CLCN2 gene existed in all four Chinese cattle breeds, while the distributions of CLCN2 copy numbers varied by variety. This may be due to the diversity of background or influenced by the growing environment. Except Qinchuan cattle, all the Chinese cattle studied were crossbred cattle from different breed combinations. On the other hand, all cattle populations were maintained in Central China, except Yunling cattle, which were raised in Southwest China. These reasons may have caused the main types of the four breeds to be different.

As for the correlation analysis, the results showed the CNV1 and CNV2 in CLCN2 were associated with growth traits including cannon circumference, body slanting length, chest girth and body weight. Yunling cattle with a decreased copy number in CNV1 and a normal copy number in CNV2 exhibited thicker cannon circumference. Xianan cattle with the normal type of CNV2 showed better phenotypes than other types. The data suggested that CNVs of the CLCN2 gene could be used as a molecular genetic marker of cattle, allowing improvement to the growth traits of cattle and accelerating the breeding process. Currently, studies on mutations of CLCN2 gene investigate brain white matter edema [39], secondary paroxysmal kinesigenic dyskinesia [40], idiopathic generalized epilepsy [41] and other diseases. Most mutations affect chloride channel function and trafficking by altering the protein encoded by CLCN2. As a member of the chloride channel family, there was a missense mutation in CLCN7 gene, accelerating the gating of the lysosomal $\mathrm{Cl}^{-} / \mathrm{H}^{-}$exchanger $\mathrm{ClC}-7 /$ Ostm1, causing osteopetrosis with gingival hamartomas in cattle [42]. Further experimental studies are required to determine the specific mechanism of action and functional differences of copy number variations between different varieties.

\section{Conclusions}

In summary, this is the first detection and validation of the two different CNVs of the CLCN2 gene in the four Chinese cattle populations. The loss type of CNV1 and the loss and normal type of CNV1 and CNV2 combination in YL was associated with increased cannon circumference, while the normal type of CNV2 was related to body slanting length, chest girth and body weight in XN. Thus, we can conclude that the loss and normal CNV types of the CLCN2 gene are related to better phenotypes in these Chinese cattle breeds. Our findings revealed CLCN2 CNVs could be used as candidate markers for cattle molecular breeding.

Author Contributions: Conceptualization, J.T. and H.C.; methodology, J.T., H.C. and X.L.; software, X.S., A.Q. and S.Y.; validation, J.T., Y.Y. and H.Y.; formal analysis, J.T. and X.S.; investigation, J.T.; resources, K.Q. and B.H.; data curation, J.T., Y.Y. and H.Y. writing-original draft preparation, J.T.; writing-review and editing, J.T. and H.C.; visualization, J.T. and X.S. supervision, H.C.; project administration, H.C. and X.L.; funding acquisition, H.C. and B.H. All authors have read and agreed to the published version of the manuscript.

Funding: This work was supported by the Program of Yunnan Provincial Major S\&T Project (2019ZG007, 2019ZG011); the Agricultural Improved Seed Project of Shandong Province (2020LZGC01403); the China Agriculture Research System of MOF and MARA (CARS-37); the Doctoral Startup Project of Chuxiong Normal University (no. BSQD2101); Yunling Scholar and the Young and Middleaged Academic Technology Leader Backup Talent Cultivation Program in Yunnan Province, China (2018HB045).

Institutional Review Board Statement: All experiments were approved by the Review Committee for the Use of Animal Subjects of Northwest A\&F University (approval file No. NWAFAC1008).

Informed Consent Statement: Not applicable.

Data Availability Statement: The study did not report any data. 
Conflicts of Interest: The authors declare no conflict of interest.

\section{References}

1. Li, X.Z.; Yan, C.G.; Zan, L.S. Current situation and future prospects for beef production in China-A review. Asian-Australas J. Anim. Sci. 2018, 31, 984-991. [CrossRef] [PubMed]

2. Margawati, E. A Global Strategy of Using Molecular Genetic Information to Improve Genetics in Livestock. Reprod. Domest. Anim. 2012, 47, 7-9. [CrossRef] [PubMed]

3. Williams, J. The use of marker-assisted selection in animal breeding and biotechnology. Rev. Sci. Tech. (Int. Off. Epizoot.) 2005, 24, 379-391. [CrossRef]

4. $\quad$ Mills, R.E.; Walter, K.; Stewart, C.; Handsaker, R.E.; Korbel, J.O. Mapping Copy Number Variation by Population-Scale Genome Sequencing. Nature 2011, 470, 59-65. [CrossRef] [PubMed]

5. Da Silva, J.M.; Giachetto, P.F.; Da Silva, L.O.; Cintra, L.C.; Paiva, S.R.; Yamagishi, M.E.B.; Caetano, A.R. Genome-wide copy number variation $(\mathrm{CNV})$ detection in Nelore cattle reveals highly frequent variants in genome regions harboring QTLs affecting production traits. BMC Genom. 2016, 17, 454. [CrossRef] [PubMed]

6. Yang, L.; Xu, L.; Zhu, B.; Niu, H.; Zhang, W.; Miao, J.; Shi, X.; Zhang, M.; Chen, Y.; Zhang, L. Genome-wide analysis reveals differential selection involved with copy number variation in diverse Chinese Cattle. Sci. Rep. 2017, 7, 14299. [CrossRef] [PubMed]

7. Thiemann, A.; Gründer, S.; Pusch, M.; Jentsch, T.J. A chloride channel widely expressed in epithelial and non-epithelial cells. Nature 1992, 356, 57. [CrossRef] [PubMed]

8. Lang, F.; Ritter, M.; Gamper, N.; Huber, S.; Fillon, S.; Tanneur, V.; Lepple-Wienhues, A.; Szabo, I.; Bulbins, E. Cell volume in the regulation of cell proliferation and apoptotic cell death. Cell. Physiol. Biochem. 2000, 10, 417-428. [CrossRef] [PubMed]

9. Okada, Y.; Maeno, E. Apoptosis, cell volume regulation and volume-regulatory chloride channels. Comp. Biochem. Physiol. Part A Mol. Integr. Physiol. 2001, 130, 377-383. [CrossRef]

10. Guan, Y.-Y.; Wang, G.-L.; Zhou, J.-G. The ClC-3 $\mathrm{Cl}^{-}$channel in cell volume regulation, proliferation and apoptosis in vascular smooth muscle cells. Trends Pharmacol. Sci. 2006, 27, 290-296. [CrossRef]

11. Voets, T.; Szücs, G.; Droogmans, G.; Nilius, B. Blockers of volume-activated Cl currents inhibit endothelial cell proliferation. Pflügers Arch. Eur. J. Physiol. 1995, 431, 132-134. [CrossRef]

12. Xiao, G.N.; Guan, Y.Y.; He, H. Effects of $\mathrm{Cl}^{-}$channel blockers on endothelin-1-induced proliferation of rat vascular smooth muscle cells. Life Sci. 2002, 70, 2233-2241. [CrossRef]

13. Rouzaire-Dubois, B.; Milandri, J.B.; Bostel, S.; Dubois, J.M. Control of cell proliferation by cell volume alterations in rat C6 glioma cells. Pflügers Arch. Eur. J. Physiol. 2000, 440, 881-888. [CrossRef]

14. O'Loughlin, E.V. Interleukin 2 modulates ion secretion and cell proliferation in cultured human small intestinal enterocytes. Gut 2001, 49, 636-643. [CrossRef]

15. Jiang, B.; Hattori, N.; Liu, B.; Nakayama, Y.; Kitagawa, K.; Inagaki, C. Suppression of cell proliferation with induction of p21 by $\mathrm{Cl}^{-}$channel blockers in human leukemic cells. Eur. J. Pharmacol. 2004, 488, 27-34. [CrossRef]

16. Hou, X.; Zhang, R.; Wang, J.; Li, Y.; Li, F.; Zhang, Y.; Zheng, X.; Shen, Y.; Wang, Y.; Zhou, L. CLC-2 is a positive modulator of oligodendrocyte precursor cell differentiation and myelination. Mol. Med. Rep. 2018, 17, 4515-4523. [CrossRef]

17. Gang, C.; Kim, M.J.; Jia, G.; Agrawal, D.K. Involvement of Chloride Channels in IGF-I -induced Proliferation of Porcine Arterial Smooth Muscle Cells. Cardiovasc. Res. 2007, 73, 198-207.

18. Sun, L.; Dong, Y.; Jing, Z.; Yin, Y.; Zheng, Y. The CLC-2 Chloride Channel Modulates ECM Synthesis, Differentiation, and Migration of Human Conjunctival Fibroblasts via the PI3K/Akt Signaling Pathway. Int. J. Mol. Sci. 2016, 17, 910. [CrossRef]

19. Rapetti-Mauss, R.; Berenguier, C.; Allegrini, B.; Soriani, O. Interplay Between Ion Channels and the Wnt/ $\beta$-Catenin Signaling Pathway in Cancers. Front. Pharmacol. 2020, 11, 525020. [CrossRef]

20. Cid, L.P.; Montrose-Rafizadeh, C.; Smith, D.I.; Guggino, W.B.; Cutting, G.R. Cloning of a putative human voltage-gated chloride channel (CIC-2) cDNA widely expressed in human tissues. Hum. Mol. Genet. 1995, 4, 407-413. [CrossRef]

21. Jentsch, T.J.; Stein, V.; Weinreich, F.; Zdebik, A.A. Molecular Structure and Physiological Function of Chloride Channels. Physiol. Rev. 2002, 82, 503-568. [CrossRef] [PubMed]

22. Kchl, S.; Niedersttter, H.; Parson, W. DNA Extraction and Quantitation of Forensic Samples Using the Phenol-Chloroform Method and Real-Time PCR. Methods Mol. Biol. 2005, 297, 13-30.

23. Yang, M.; Lv, J.; Zhang, L.; Li, M.; Hong, C. Association study and expression analysis of CYP4A11 gene copy number variation in Chinese cattle. Sci. Rep. 2017, 7, 46599. [CrossRef] [PubMed]

24. Yang, L.; Xu, L.; Zhou, Y.; Liu, M.; Wang, L.; Kijas, J.W.; Zhang, H.; Li, L.; Liu, G.E. Diversity of copy number variation in a worldwide population of sheep. Genomics 2017, 110, 143-148. [CrossRef]

25. Redon, R.; Ishikawa, S.; Fitch, K.R.; Feuk, L.; Perry, G.H.; Andrews, T.D.; Fiegler, H.; Shapero, M.H.; Carson, A.R.; Chen, W.; et al. Global variation in copy number in the human genome. Nature 2006, 444, 444-454. [CrossRef]

26. Feuk, L.; Carson, A.R.; Scherer, S.W. Structural variation in the human genome. Nat. Rev. Genet. 2006, 7, 85-97. [CrossRef]

27. Griffin, D.K.; Robertson, L.B.; Tempest, H.G.; Vignal, A.; Fillon, V.; Crooijmans, R.P.M.A.; Groenen, M.A.M.; Deryusheva, S.; Gaginskaya, E.; Carré, W.; et al. Whole genome comparative studies between chicken and turkey and their implications for avian genome evolution. BMC Genom. 2008, 9, 168. [CrossRef] 
28. Ramayo-Caldas, Y.; Castelló, A.; Pena, R.N.; Alves, E.; Mercadé, A.; Souza, C.A.; Fernández, A.I.; Perez-Enciso, M.; Folch, J.M. Copy number variation in the porcine genome inferred from a $60 \mathrm{k}$ SNP BeadChip. BMC Genom. 2010, 11, 593. [CrossRef]

29. Wang, Z.; Guo, Y.; Liu, S.; Meng, Q. Genome-Wide Assessment Characteristics of Genes Overlapping Copy Number Variation Regions in Duroc Purebred Population. Front. Genet. 2021, 12. [CrossRef]

30. Liu, G.E.; Hou, Y.; Zhu, B.; Cardone, M.F.; Jiang, L.; Cellamare, A.; Mitra, A.; Alexander, L.J.; Coutinho, L.L.; Dell'Aquila, M.E.; et al. Analysis of copy number variations among diverse cattle breeds. Genome Res. 2010, 20, 693-703. [CrossRef]

31. Mei, C.; Junjvlieke, Z.; Raza, S.H.A.; Wang, H.; Cheng, G.; Zhao, C.; Zhu, W.; Zan, L. Copy number variation detection in Chinese indigenous cattle by whole genome sequencing. Genomics 2020, 112, 831-836. [CrossRef]

32. Liu, J.; Zhang, L.; Xu, L.; Ren, H.; Lu, J.; Zhang, X.; Zhang, S.; Zhou, X.; Wei, C.; Zhao, F.; et al. Analysis of copy number variations in the sheep genome using 50K SNP BeadChip array. BMC Genom. 2013, 14, 229. [CrossRef]

33. Lupski, J.R.; Stankiewicz, P. Genomic disorders: Molecular mechanisms for rearrangements and conveyed phenotypes. PLoS Genet. 2005, 1, e49. [CrossRef]

34. Strillacci, M.G.; Gorla, E.; Cozzi, M.C.; Vevey, M.; Bagnato, A. A Copy Number Variant (CNV) scan in the autochthonous Italian Valdostana Red Pied cattle and comparison with specialized dairy populations. PLoS ONE 2018, 13, e0204669. [CrossRef]

35. Lee, Y.-L.; Bosse, M.; Mullaart, E.; Groenen, M.A.M.; Veerkamp, R.F.; Bouwman, A.C. Functional and population genetic features of copy number variations in two dairy cattle populations. BMC Genom. 2020, 21, 89. [CrossRef]

36. Jentsch, T.J.; Poët, M.; Fuhrmann, J.C.; Zdebik, A.A. PHYSIOLOGICAL FUNCTIONS OF CLC Cl-CHANNELS GLEANED FROM HUMAN GENETIC DISEASE AND MOUSE MODELS. Annu. Rev. Physiol. 2005, 67, 779-807. [CrossRef]

37. Bösl, M.R.; Stein, V.; Hübner, C.; Zdebik, A.A.; Jordt, S.-E.; Mukhopadhyay, A.K.; Davidoff, M.S.; Holstein, A.-F.; Jentsch, T.J. Male germ cells and photoreceptors, both dependent on close cell-cell interactions, degenerate upon $\mathrm{ClC}_{-} 2 \mathrm{Cl}^{-}$channel disruption. EMBO J. 2001, 20, 1289-1299. [CrossRef]

38. Lang, F.; Föller, M.; Lang, K.; Lang, P.; Ritter, M.; Vereninov, A.; Szabo, I.; Huber, S.M.; Gulbins, E. Chapter Eleven-Cell Volume Regulatory Ion Channels in Cell Proliferation and Cell Death. In Methods in Enzymology; Häussinger, D., Sies, H., Eds.; Academic Press: Cambridge, MA, USA, 2007; Volume 428, pp. 209-225.

39. Depienne, C.; Bugiani, M.; Dupuits, C.; Galanaud, D.; Touitou, V.; Postma, N.; Van Berkel, C.; Polder, E.; Tollard, E.; Darios, F.; et al . Brain white matter oedema due to ClC-2 chloride channel deficiency: An observational analytical study. Lancet Neurol. 2013, 12, 659-668. [CrossRef]

40. Hanagasi, H.A.; Bilgiç, B.; Abbink, T.E.M.; Hanagasi, F.; Tüfekçioğlu, Z.; Gürvit, H.; Başak, N.; Van der Knaap, M.S.; Emre, M. Secondary paroxysmal kinesigenic dyskinesia associated with CLCN2 gene mutation. Parkinsonism Relat. Disord. 2015, 21, 544-546. [CrossRef]

41. Saint-Martin, C.; Gauvain, G.; Teodorescu, G.; Gourfinkel-An, I.; Fedirko, E.; Weber, Y.G.; Maljevic, S.; Ernst, J.-P.; Garcia-Olivares, J.; Fahlke, C.; et al. Two novel CLCN2 mutations accelerating chloride channel deactivation are associated with idiopathic generalized epilepsy. Hum. Mutat. 2009, 30, 397-405. [CrossRef]

42. Sartelet, A.; Stauber, T.; Coppieters, W.; Ludwig, C.F.; Fasquelle, C.; Druet, T.; Zhang, Z.; Ahariz, N.; Cambisano, N.; Jentsch, T.J.; et al. A missense mutation accelerating the gating of the lysosomal $\mathrm{Cl}^{-} / \mathrm{H}^{+}$-exchanger ClC-7/Ostm1 causes osteopetrosis with gingival hamartomas in cattle. Dis. Models Mech. 2014, 7, 119-128. [CrossRef] 